\title{
TEACHING TRANSLATION OF ENGLISH-SERBIAN FALSE FRIENDS TO PRIMARY-SCHOOL PUPILS - A NEW APPROACH ${ }^{1}$
}

\author{
JASNA KAPELAN² \\ University of Novi Sad, \\ Faculty of Philosophy, \\ Novi Sad, Serbia
}

Ovaj rad bavi se prevođenjem englesko-srpskih lažnih parova na srpski jezik. Istraživanje je sprovedeno u osnovnoj školi među 22 učenika sedmog razreda osnovne škole. 14 formalnih i sadržinskih englesko-srpskih lažnih parova koristi se u radu, kao i 6 skrivenih anglicizama. Ističu se tri cilja rada, a to su: prvo, da se pomogne učenicima da prevaziđu prepreke na koje nailaze dok prevode englesko-srpske lažne parove na srpski jezik, drugo, da se pomogne učenicima da pronađu odgovarajuće prevodne ekvivalente za 20 englesko-srpskih lažnih parova i treće, da se uvedu pojedini elementi kontaktne jezičke kulture u nastavu engleskog jezika kao stranog. Očekuje se da, ako učenici pronađu sličnosti i razlike među englesko-srpskim lažnim parovima i ako uče englesko-srpske lažne parove kroz kreativne aktivnosti, pravilno će ih prevoditi. Prevođenje se koristi kao način traženja sličnosti i razlika između englesko-srpskih lažnih parova. Greške učenika u prevođenju su izdvojene, zatim razvrstane, a posle toga su pronađena i područja poteškoća u prevođenju u ciljnom jeziku. Kao posledica toga, lažni parovi su podeljeni u tri grupe: odgovarajući, neuobičajeni i neprihvatljivi lažni parovi.

Ključne reči: lažni prijatelji, predavanje, prevođenje, učenici, engleski jezik, srpski jezik.

1 This paper originates from the research entitled "Teaching English false friends to seventh-grade primaryschool pupils" which was done for the subject Contrastive lexicology during the first year of the doctoral studies at the Faculty of Philosophy in Novi Sad under the supervision of Professor Tvrtko Prćić.

2 Kontakt podaci (Email): majakol@abakusbp.net 


\section{INTRODUCTION}

False friends represent a widely-known language phenomenon. According to Simić (2008: 17), they are the words from different languages which have similar or identical graphic-orthographical or phonological form or belong to the same part of speech, but their meanings differ partially or completely; at the same time, they are the words from different languages which differ in form, but their meanings overlap to some extent, only in certain contexts. As Prćić (2012: 203) notices, because of quite unpredictable and deceitful formal and content-related inter-relations, false friends are a potential and real problem not only for translators, but for all other people who study a foreign language. Among 20 English-Serbian false friends which are used in this research, there are 6 hidden anglicisms. As Prćić (2005: 121-122) explains, a Serbian word, syntagm or a sentence can maintain English usage norm. In these cases, meanings and/ or the usage of a word, typical of English forms, are hidden in the forms of Serbian, which are naturalized relatively fast and in this way hidden anglicisms are created.

Boumali (2009-2010: 1-2) notices that when applied linguists tried to identify the root of errors in translation, they found out that false friends belong to one of the most significant areas of difficulties met by learners in their translation. Learners of foreign languages usually draw on their previous knowledge, especially if the source language and the target language have a lot of similarities. In translation, most of them fall in the trap of false friends because of this reliance. Lado (1957: 84) puts false friends to the highest position on the scale of difficulty and he calls them "sure-fire trap". Since this research investigates the problems caused by false friends in translation, it is hypothesized that if translation learners identify the similarities and the differences between the source language (English) and the target language (Serbian) they can avoid the trap of false friends.

This research is also an effort for introducing contact language culture in language teaching in a primary school. According to Prćić (2005: 186), contact language culture represents a detailed standardized strategy for adequate approach to English words and names and their consistent use in Serbian, in order for us to reduce, place within rational limits and in the end to dismiss today's situation of using words, in which the lack of organization and abundance of variations used without aim or purpose command. It seems that if teachers show their pupils how to use English-Serbian false friends correctly, they can also help them use English in real-life situations and they can improve their teaching process. Thus, if teachers want to introduce contact language culture in language teaching in a primary school, they should adjust the curriculum in such a way that it deals with language usage in different contexts. On the other hand, they have to give their pupils a chance to correct inadequate translations of English movies, for example.

Prćić (2012: 204) notices that false friends are studied in many languages from a theoretical and practical point of view. Books and articles whose topic is "false friends" deal with teaching translation of false friends, contrastive linguistics, contact linguistics, teaching methodology of foreign languages, lexicography and lexicology (an online bibliography until 2006 is provided by Bunčić 2006). Some examples of them are the following: Chamizo Dominguez 1999; 2006; 2010; Chamizo Dominguez/Nerlich 
2002; Gouws et al. 2004; Granger/Swallow 1988; Kessler/Derocquigny 1928; Szpila 2005. Theoretical and practical aspects of studying Serbian-English and English-Serbian false friends are described by Ivir 1968; 1981; 1985; Gajić 1984; 1985; Buntić 1994; Đukanović 2003; Felbabov 1999; Karavesović 2007 and Simić 2008, as well as in two dictionaries: Hlebec 1997 and Kovačević 2011.

This article is organized in the following way: in the second section basic ways for teaching English vocabulary and some factors which have a great influence on teaching translation of English-Serbian false friends are described, in the third section the methodology and the results of the research are given, and the fourth section represents the discussion and conclusions of the paper.

\section{TEACHING TRANSLATION OF ENGLISH-SERBIAN FALSE FRIENDS}

While teaching English-Serbian false friends to my pupils I tried to follow methodological requirements proposed by Cameron (2005), Nation (2001) and Thornbury (2002). Namely, Cameron $(2005: 74,81)$ points out that learning vocabulary represents a cyclical process of meeting words and that initial learning should be followed by meeting these words again and again, each time extending their meaning and how they should be used in a foreign language. It is also important to expand and deepen word knowledge. Nation (2001: 74-77) points out that if children use new words in different contexts in appropriate ways, they will remember them better. Thornbury (2002: 75-76) claims that when a teacher wants to teach her students new words, she has to take into account the following factors: "the level of the learners (whether beginners, intermediate, or advanced), the learner's likely familiarity with the words (learners may have met the words before even though they are not part of their active vocabulary), the difficulty of the items (whether they express abstract rather than concrete meaning), their "teachability" (whether they can be easily explained or demonstrated), whether items are being learned for production (in speaking and writing) or for recognition only (as in listening and reading)." Thornbury (2002: 7781) also says that students should study new words through games, actions/ gestures, different situations, by giving several example sentences and through other interesting activities, rather than by translating words. This author also points out that translation is the most direct route to a word's meaning, but because of the fact that students do not have to work hard to access the meaning, it may mean that the word is less memorable. In this paper the level of the learners is intermediate, learners had not met English-Serbian false friends in classes before, although there is a high possibility that they had had an opportunity to find them on television or on the Internet, or in their immediate environment. English-Serbian false friends used in this research usually express abstract meaning and they cannot be easily explained to pupils. They are being learned for production (in speaking and writing).

Ivir (1985: 11) defines the act of translation as transforming the message previously expressed by one language into the message expressed by another language. During this research translation is used as a way of finding differences and similarities among English-Serbian false friends concerning the level of form and content. Tertium 
comparationis represents a mutual characteristic of both lexical units, which enables their comparison. (Bugarski 1996, Đorđević 2004, Krzeszowski 1990). According to Ivir (1985: 103-109), there are three types of semantic relations connected by tertium comparationis, which are important for English-Serbian false friends: first, words which have the same meaning in both languages, but they differ in their use, second, pairs with completely different meanings and third, English-Serbian false friends with partial overlapping in meaning.

Prćić (2012: 217) recognizes the importance of teaching English-Serbian false friends to pupils from a beginner's level of studying English. Namely, a teacher should explain some practical aspects of English-Serbian false friends to her pupils and they should be aware of delusiveness and enticement of orthographically similar groups of words. Formal English-Serbian false friends do not have recognizable signs except for their orthographical similarity, so pupils should be suspicious of every orthographically similar pair of words, for which there is a high possibility that they are neither similar nor the same and whose meaning and form must be checked in quality English and Serbian printed and electronic dictionaries. The biggest, the most challenging and the most creative problem of translating English-Serbian false friends is finding a correct equivalent in the target language for content-related false friends, which express lexical and sometimes even conceptual gaps and for which ready solutions, in most cases, do not exist. It is quite important for pupils to know that, if a word in English has a similar form as a word in Serbian, it does not necessarily mean that these two words have the same meaning.

Describing some factors which are quite important for acquiring English-Serbian false friends Simić (2008: 36) emphasizes the fact that pupils' mother tongue has a great influence on them while they compare and contrast grammatical and lexical elements in two languages. Namely, if pupils have to translate real pairs which are similar in orthographic form and meaning, they will not have a difficult task. Quite the contrary, if pupils have to translate English-Serbian false friends which are similar in orthographic form, but different in meaning, they are likely to make serious mistakes. For example, under the influence of their mother tongue, (Serbian), pupils will translate English words like actually and eventually as aktuelno and eventualno, which is incorrect.

\section{METHODOLOGY OF THE RESEARCH}

The research was conducted in the primary school "Vuk Karadžić" in Bačka Palanka among 22 seventh-grade primary-school pupils (12 girls and 10 boys).

The aims of the research are the following:

1. to help the seventh-grade primary-school pupils overcome some obstacles they have while translating English-Serbian false friends into Serbian,

2. to help them find the adequate equivalents for 20 English-Serbian false friends and

3. to introduce some elements of contact language culture into teaching English as a foreign language. 
Since I had an opportunity to teach the pupils who took part in this research from the first grade of a primary school, I found out that they had some difficulties in studying English vocabulary. For example, they sometimes do not translate an English word with an appropriate Serbian equivalent, but they translate it literally or they even leave its original written form instead. The reasons for this phenomenon can be the following: pupils can see inadequate usage of English everywhere, for example in Serbian newspapers and magazines, on TV, or on the Internet and they are under the significant influence of their mother tongue. Consequently, they get confused and do not know when and how to use which language. Thus, one of specific aims of this research was to help them realize that although these two languages have an important influence over each other, they have to be used properly.

Twenty English-Serbian false friends and their translation equivalents which were used in this research were found in Srpsko-engleski rečnik lažnih parova (Hlebec 1997), Engleski u srpskom (Prćić 2005) and in Du yu speak anglosrpski? Rečnik novijih anglicizama (Vasić, Prćić, Nejgebauer 2011) respecting two criteria: pupils' age (they are 13 or 14 years old) and the level of knowledge (intermediate) must be taken into account. The English-Serbian false friends selected for the corpus are often used in Serbian television shows and in pupils' environment inadequately and usually translated literally, so this research is an attempt for pupils to finally understand the meanings of these English-Serbian false friends. Among 20 English-Serbian false friends there are 6 hidden anglicisms, such as the formal English-Serbian false friends definitely, massive, originally, positive and the content-related English-Serbian false friends encourage and short story. Then, there is a group of not so complicated English-Serbian false friends for understanding (affair, command, control, game, situated, stop) and, finally, there is the third group which contains English-Serbian false friends which are expected to cause the most significant problems to pupils (actual, argument, brutal, delicate, eventually, novel, vein and virtually). The English-Serbian false friends which belong to the second and the third group are all formal, except for the word novel, which is a content-related English-Serbian false friend. The reasons for using hidden anglicisms and abstract English-Serbian false friends which belong to the third group of the corpus are found in Prćić $(2005: 17,25,29,73,83.200)$. Namely, today, the mixing of a mother tongue with English is widely used by young people as well as by experts and in popular printed and electronic media (mostly on television and on the Internet). Besides, English is very often used for the naming of domestic products, factories and shops, pop groups and songs, television and radio shows, magazines, plays and cultural events. Also, English words are used without control, regardless of the fact whether they are needed or justified and only their form is copied, while their content is insufficiently clear and inadequately established. Consequently, under the influence of English and because of surface translation Serbian people usually do not recognize English-Serbian false friends. Insufficient knowledge of words, especially of content-related English-Serbian false friends, is the reason why new meanings of domestic or naturalized words are developed, for example short story is translated as *kratka priča instead of pripovetka. As a result, in primary and secondary schools the curriculum of English as a foreign language should be broadened with the elements of contrastive analysis and with English-Serbian language contacts, focusing on proper translation of content of a text, 
instead of inert copying of its form. Pupils should develop a mental mechanism for preventing negative transmission from English into Serbian and English-Serbian contact and contrastive aspects should be taken into account. Since formal and content-related English-Serbian false friends and hidden anglicisms represent an important element of English-Serbian contact language culture, they should be studied in primary schools especially in the seventh and the eighth grade. Namely, older pupils (aged 13 or 14) can grasp their abstract meaning with a teacher's help whose task is to provide creative activities for this purpose, some of which will be described in this paper. Besides, studying English-Serbian false friends can help pupils in using English language in real-life situations, which is one of the most important functions of teaching foreign languages. To sum up, pupils should be aware that English-Serbian false friends exist and that they should be recognized, used adequately in certain contexts and compared and contrasted in English and in Serbian. A lot of examples of English-Serbian false friends, including abstract and more complicated ones can be of great help for pupils in completing this task.

Since in the curriculum there is not a lesson about English-Serbian false friends, I wanted to expand pupils' knowledge about this topic. This is a complex unit even for excellent learners of English as a foreign language, so it would be difficult to explain it to pupils and even more complicated to make them remember some examples. Consequently, it was expected that pupils would not recognize all English-Serbian false friends at the first class. Because of that, I did not want to give them a test in which they had to translate some sentences at the beginning of the research. Instead, pupils practiced English-Serbian false friends together, as a class, with my help. After the period of reception (six weeks), it was expected that a lot of pupils would remember several English-Serbian false friends that we practiced in various contexts and in different exercises and, as a result, provide more correct answers in exercises and more adequate translations. In the following table all activities which were used in the research are presented in such a way that three categories (the type of the activity, duration and interaction) of each activity are described in detail.

\begin{tabular}{|l|l|l|}
\hline 1. Type of the activity & 2. Duration & 3. Interaction \\
\hline $\begin{array}{l}\text { 1. Introduction (theoretical and practical } \\
\text { explanation) }\end{array}$ & One class - 35 minutes & $\begin{array}{l}\text { The whole } \\
\text { class }\end{array}$ \\
\hline $\begin{array}{l}\text { 2. The first test (translating the sentences } \\
\text { with the English-Serbian false friends from } \\
\text { English into Serbian) }\end{array}$ & One class - 45 minutes & $\begin{array}{l}\text { Individual } \\
\text { work }\end{array}$ \\
\hline 3. Results of the test and the error analysis & One class - 40 minutes & $\begin{array}{l}\text { The whole } \\
\text { class }\end{array}$ \\
\hline
\end{tabular}




\begin{tabular}{|c|c|c|}
\hline 1. Type of the activity & 2. Duration & 3. Interaction \\
\hline $\begin{array}{l}\text { 4. Creative activities for remembering English- } \\
\text { Serbian false friends and their meanings } \\
\text { in different contexts (1. matching English- } \\
\text { Serbian false friends with correct definitions, } \\
\text { 2. writing a story using the given English- } \\
\text { Serbian false friends in groups, 3. making } \\
\text { posters with the given English-Serbian false } \\
\text { friends and presentation) }\end{array}$ & $\begin{array}{l}\text { Six classes } \\
\text { 1. } 10 \text { minutes } \\
\text { 2. } 25 \text { minutes } \\
\text { 3. making posters } \\
\text { - homework (one } \\
\text { week); presentation - } \\
15 \text { minutes }\end{array}$ & $\begin{array}{l}\text { 1. Pair work } \\
\text { 2. Group work } \\
\text { 3. Group work }\end{array}$ \\
\hline $\begin{array}{l}\text { 5. The final test } \\
\text { (1. an example with an English-Serbian false } \\
\text { friend is given and pupils have to circle the } \\
\text { appropriate answer among three answers } \\
\text { to find out the correct meaning of the } \\
\text { English-Serbian false friend, 2. matching } \\
\text { English-Serbian false friends with the correct } \\
\text { definitions and descriptions } \\
\text { 3. translating the sentences with the English- } \\
\text { Serbian false friends from English into Serbian) }\end{array}$ & One class - 45 minutes & $\begin{array}{l}\text { Individual } \\
\text { work }\end{array}$ \\
\hline 6. Results of the test and the error analysis & One class - 40 minutes & $\begin{array}{l}\text { The whole } \\
\text { class }\end{array}$ \\
\hline
\end{tabular}

Table 1: A model for teaching translation of English-Serbian false friends from English into Serbian for the period of six weeks

\section{RESULTS OF THE RESEARCH}

When analyzing pupils' mistakes I followed some pieces of advice of Prćić (2012: 204), who says that English-Serbian false friends should be questioned, described, explained, defined, classified and codified to help pupils recognize them and understand them better and use them appropriately. The error analysis which is used in this research consists of the following steps: English-Serbian false friends are collected first, then errors are identified and classified and the areas of difficulty in the target language are identified. (Boumali 2009-2010: 8). In the following table, the results of the error analysis of 5 English-Serbian false friends are presented. First, an English-Serbian false friend is given and then an example with the English-Serbian false friend and the expected and the adequate translation of that sentence are presented. After that, partly acceptable (imprecisely formulated) and inadequate translations are written and based on them, the following types of the English-Serbian false friends are found: unacceptable English-Serbian false friends, unusual English-Serbian false friends, while expected and correct translations of English-Serbian false friends belong to the group of adequate English-Serbian false friends. The number of pupils is provided for each category of translations. 


\begin{tabular}{|c|c|c|c|}
\hline ف & 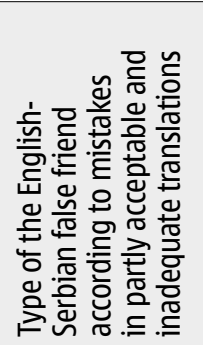 & 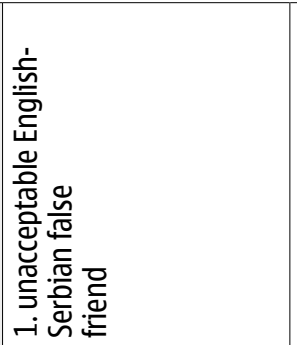 & 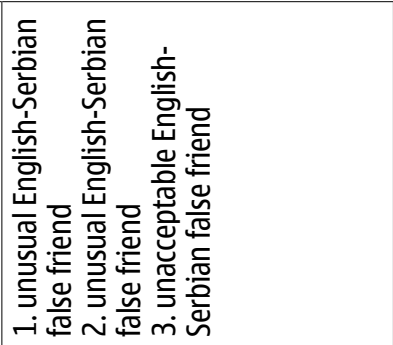 \\
\hline نं & 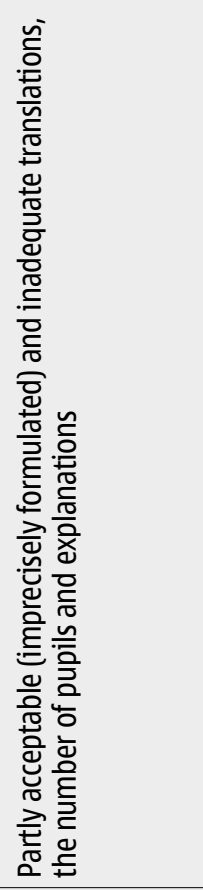 & 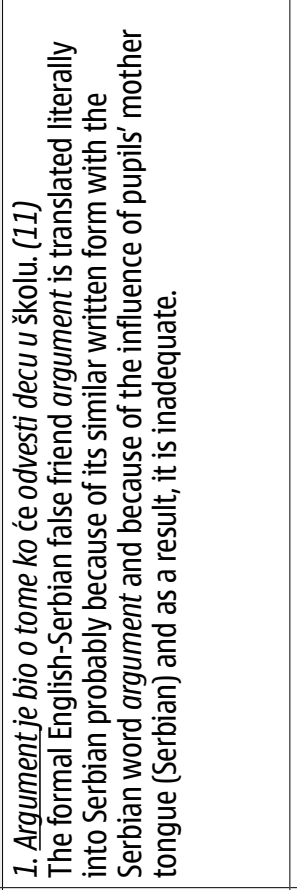 & 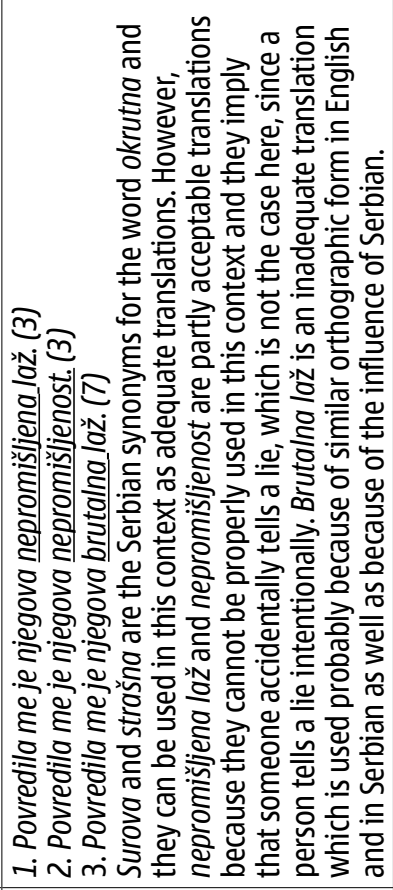 \\
\hline$\dot{\nabla}$ & 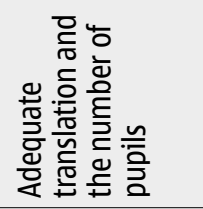 & 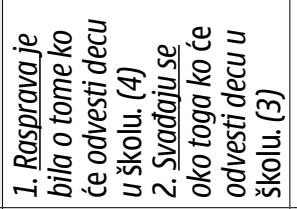 & 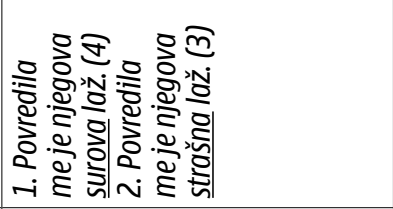 \\
\hline$\dot{m}$ & 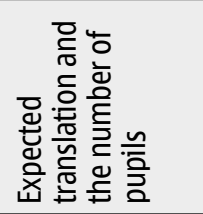 & 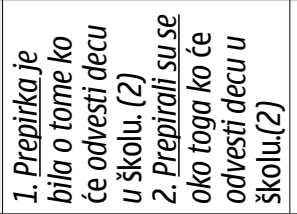 & 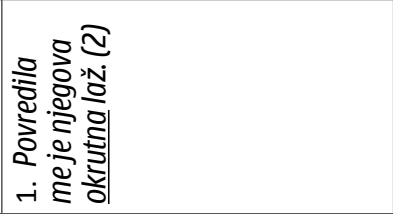 \\
\hline ن & 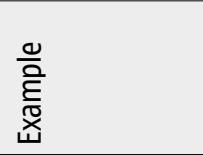 & 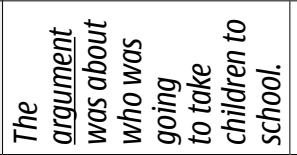 & 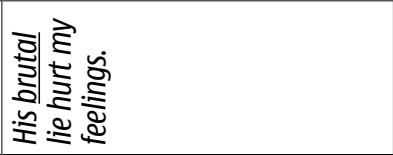 \\
\hline & 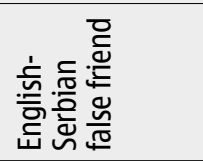 & 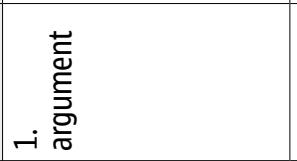 & $\sim \underset{\frac{\pi}{2}}{\sim}$ \\
\hline
\end{tabular}




\begin{tabular}{|c|c|c|}
\hline 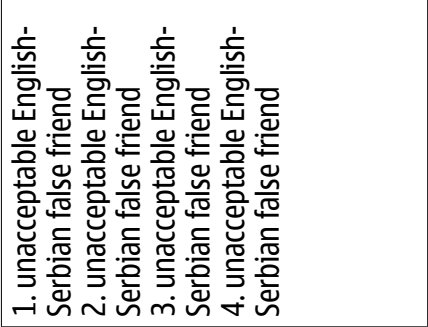 & 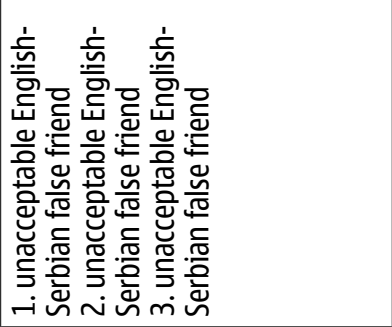 & 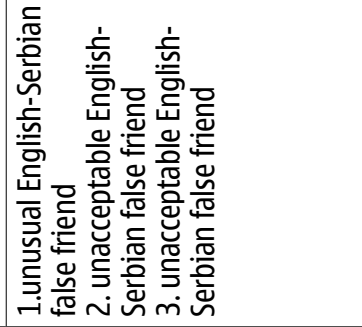 \\
\hline 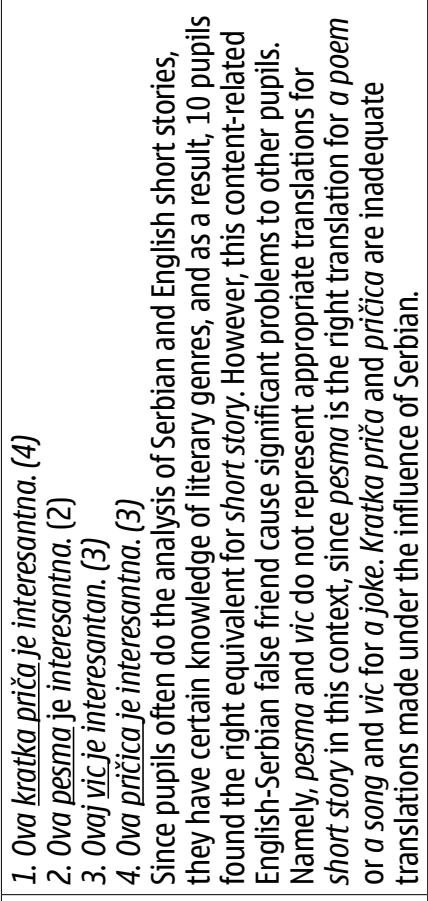 & 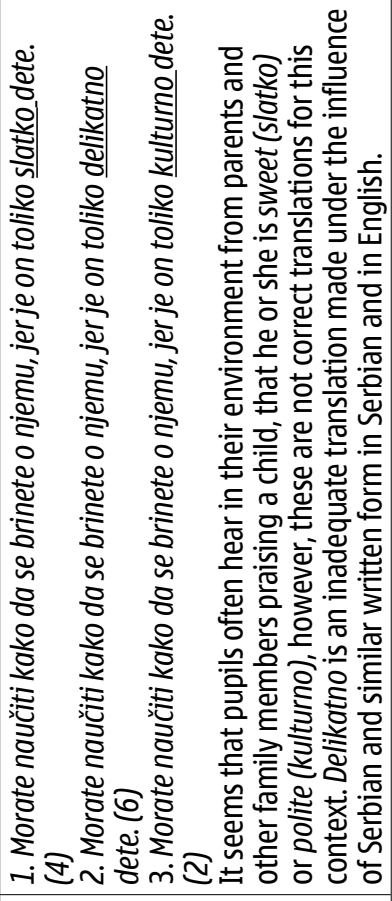 & 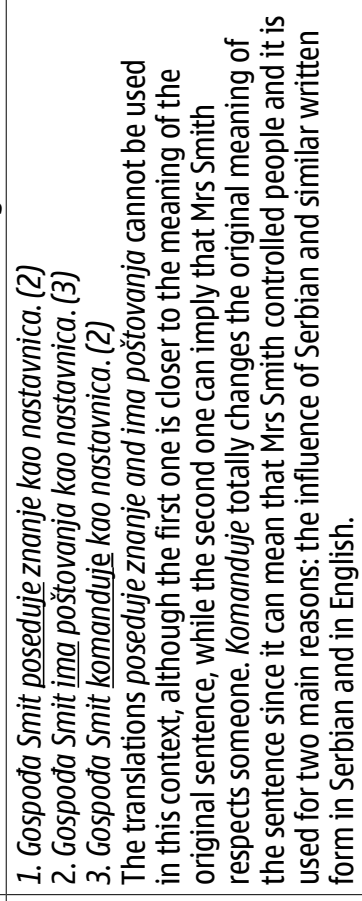 \\
\hline 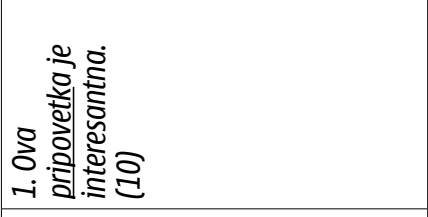 & 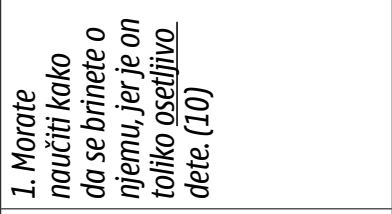 & 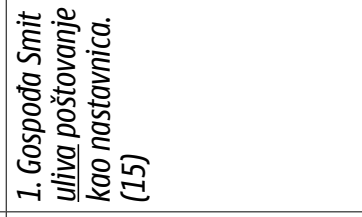 \\
\hline 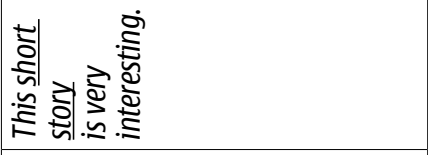 & 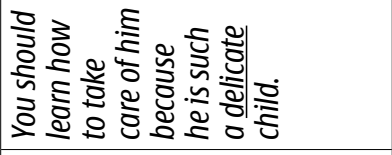 & 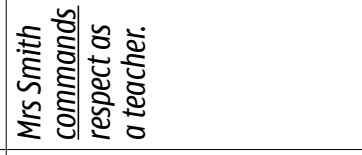 \\
\hline $\begin{array}{r}\frac{2}{0} \\
\frac{ \pm}{n} \\
\text { mi } \\
\text { m } \\
\end{array}$ & + & 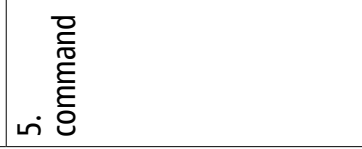 \\
\hline
\end{tabular}


As it can be seen from the table, unusual English-Serbian false friends are partly acceptable or imprecisely formulated Serbian words whose meaning is similar with the English false friends, while unacceptable English-Serbian false friends in Serbian represent inadequate translations which are probably provided under the influence of pupils' mother tongue (similar written form). As it was expected, the highest number of adequate translations is provided for the formal English-Serbian false friend command, while pupils have a lot of problems to find the correct translation for the formal EnglishSerbian false friends brutal, delicate and argument and for the content-related EnglishSerbian false friend short story.

While doing this research, I came up with creative ideas which can be put into practice through new activities for acquiring and translating English-Serbian false friends. In the following table a model of new activities for teaching translation of English-Serbian false friends from English into Serbian in the future work for the period of ten weeks is described.

\begin{tabular}{|l|l|l|}
\hline 1. Type of the activity & 2. Duration & 3. Interaction \\
\hline $\begin{array}{l}\text { 1. Finish the story by using the given English-Serbian } \\
\text { false friends }\end{array}$ & $\begin{array}{l}\text { Two classes - } \\
25 \text { minutes }\end{array}$ & Group work \\
\hline $\begin{array}{l}\text { 2. Listening to songs with English-Serbian false } \\
\text { friends and doing fill-in exercises }\end{array}$ & $\begin{array}{l}\text { Two classes - } \\
15 \text { minutes }\end{array}$ & Pair work \\
\hline $\begin{array}{l}\text { 3. Finding inappropriate translations of English- } \\
\text { Serbian false friends in movies }\end{array}$ & $\begin{array}{l}\text { Two classes - } \\
40 \text { minutes }\end{array}$ & Group work \\
\hline 4. Making their own songs & $\begin{array}{l}\text { Two classes - } \\
15 \text { minutes }\end{array}$ & Group work \\
\hline $\begin{array}{l}\text { 5. Making a script for a play in which English-Serbian } \\
\text { false friends will be used }\end{array}$ & $\begin{array}{l}\text { One class - 45 } \\
\text { minutes } \\
\text { homework - } \\
\text { one week }\end{array}$ & Group work \\
\hline 5. Rehearsing the play & $\begin{array}{l}10 \text { classes - } \\
30 \text { minutes }\end{array}$ & $\begin{array}{l}\text { The whole } \\
\text { class }\end{array}$ \\
\hline
\end{tabular}

Table 3: A model of new activities in teaching translation of English-Serbian false friends from English into Serbian in the future work for 10 weeks

\section{DISCUSSION AND CONCLUSIONS}

In this research English-Serbian false friends were questioned, described, explained, defined, classified and codified to help pupils recognize them and understand them better and use them adequately. The error analysis contained the collection of EnglishSerbian false friends as well as the identification and classification of pupils' errors and 
the description of the areas of difficulty in the target language. On the basis of the errors in pupils' translations, the following types of the English-Serbian false friends were found: unacceptable English-Serbian false friends, unusual English-Serbian false friends, while expected and correct translations of English-Serbian false friends belonged to the group of adequate English-Serbian false friends. This kind of error analysis is extremely useful for finding the reasons why pupils make mistakes, which can also help other teachers of English as a foreign language in more efficient teaching of English-Serbian false friends.

Comparing the results of practicing English-Serbian false friends at the beginning of the research and of the final test, it can be concluded that pupils had more correct answers at the end of the research, so we fulfilled the aims of our research. Namely, during this research we managed to help our pupils overcome some obstacles they had when they translated English-Serbian false friends into Serbian. Also, we helped them find the appropriate equivalents for 20 English-Serbian false friends and we introduced some elements of contact language culture into teaching English as a foreign language. We also achieved the specific aim of the research, which was to help pupils realize that although English and Serbian have a very important influence over each other, they have to be used appropriately.

The error analysis described in this research shows that pupils made mistakes in translation probably because of the fact that they are under the major influence of their mother tongue and they can see the abusage of English everywhere, especially through the media. Pupils made even more mistakes when translating hidden anglicisms, which is not surprising, because these words are usually difficult for understanding. Although translation can be seen as the direct route to a word's meaning, in this research it is used to help the pupils become aware of the existence of English-Serbian false friends and to learn how to recognize them, use them properly in certain contexts and compare and contrast them in English and in Serbian. It is noticeable that Serbian, as their mother tongue enormously influences pupils when they translate English-Serbian false friends, especially those ones which are similar in orthographic form, but different in meaning. Obviously, pupils can acquire and translate a lot of English-Serbian false friends in an appropriate way if contexts in which they are used are adjusted to their age and the level of their knowledge.

The implications for more effective teaching of English-Serbian false friends include practicing translation by using creative activities and different types of classroom interaction and using words in sentences (in the context). This kind of teaching EnglishSerbian false friends helps pupils use their creativity and makes them think about a teaching matter. By using words in different contexts they really understand various meanings of the words, even of the abstract ones. Namely, pupils get better results when they make posters on their own and present them to other pupils and when they write stories about pictures and give performances to their classmates, that is, when they see what they learn rather than when a teacher simply asks them to translate English-Serbian false friends into Serbian. In this way pupils become active agents in a creative teaching process. During this research, pupils completed the task of writing a story successfully through communication with others in their group and they were expected to interact with each other more than with the teacher. However, I controlled their work by trying to spend equal period of time near each group. If they needed some help, I encouraged them to provide their own examples by giving my examples in similar contexts. Thus, I became an advisor and a facilitator. The pupils' stories 
were very creative and they used English-Serbian false friends in different contexts. These activities helped my pupils be at the centre of my preoccupations, which is very important for the successful teaching process.

It can also be concluded that teaching English-Serbian false friends to pupils from early stages is quite important. In this way, pupils will be aware of the fact that English-Serbian false friends exist and that, if a word in English has a similar form as a word in Serbian, it does not usually mean that these two words have the same meaning. By introducing the topic "false friends" to my classes, I have created the addition to the curriculum, which is a big step towards introducing contact language culture in language teaching in a primary school. It will be quite important that in primary and secondary schools the curriculum of English as a foreign language should be broadened with the elements of contrastive analysis and with English-Serbian language contacts, focusing on proper translation of content of a text, instead of inert copying of its form. In this way, pupils will develop a mental mechanism for preventing negative transmission from English into Serbian. Since formal and content-related English-Serbian false friends and hidden anglicisms represent a significant element of English-Serbian contact language culture, they should be studied in primary schools especially in the seventh and the eighth grade because older pupils can understand their abstract meaning with a teacher's help whose role is to provide creative activities for this aim, some of which were described in this article. Studying English-Serbian false friends helped my pupils use the English language in real-life situations, which is quite important for improving the teaching process. Consequently, pupils recognized a lot of examples of English-Serbian false friends, including abstract and more complicated ones and used them appropriately in certain contexts. Also, the model of new activities for teaching translation of English-Serbian false friends from English into Serbian in the future work for the period of ten weeks which was described in this paper can help teachers organize their classes concerning English-Serbian false friends and also improve their teaching process.

In my future research, it would be useful to provide the error analysis of pupils' translations of English-Serbian false friends in the way described in this paper with other classes, too, and to compare these results of the study to that of pupils who did not have special classes on English-Serbian false friends. Thus, what can make this research even better is creating a control group, which can be one class of pupils who did not study English-Serbian false friends according to this approach, for comparing and contrasting the results of the control and the experimental group. In this way, we can get a clear image of the advantages of teaching English-Serbian false friends based on the model described in this paper.

\section{REFERENCES}

Boumali, A. 2009-2010. False Friends: a Problem Encountered in Translation. Mentouri University - Constatine, Faculty of Letters and Languages, Department of Languages. A dissertation Submitted in Partial Fulfillment for Master Degree in Applied Language Studies. [Internet]. Available at: http: //www.umc.edu.dz/buc/ theses/anglais/B0U1153.pdf [19.5. 2012]. 
Bugarski, R. 1996. Lingvistika u primeni. Beograd: Čigoja štampa.

Buntić, D. 1994. Lažni prijatelji u lingvistici. Kruševac: Viša tehnološko-tehnička škola.

Bunčić, D. 2006. An On-line Hypertext Bibliography on False Friends. [Internet]. Available at: http://www.lipczuk.buncic.de/ [11. 5. 2014].

Chamizo Dominguez, J. P. 1999. False Friends: Mousetraps for Communication and Translation. International Journal of Communication 9/1-2, 115-130.

Chamizo Dominguez, J. P. False Friends. 2006. In K. Brown (ed.) Encyclopedia of Language and Linguistics. Vol. 4, 2nd edition. Oxford: Elsevier, 426-429.

Chamizo Dominguez, J. P. 2010. Semantics and Pragmatics of False Friends. 2nd edition. London/New York: Routledge.

Chamizo Dominguez, J. P. and B. Nerlich. 2002. False Friends: Their Origin and Semantics in Some Selected Languages. Journal of Pragmatics 34/12, 1833-1849.

Cameron, L. 2005. Teaching Languages to Young Learners. Cambridge: CUP.

Đorđević, R. 2004. Uvod u kontrastiranje jezika. 6. izdanje. Beograd: Filološki fakultet.

Đukanović, M. 2003. Lažni prijatelji. Svet reči: časopis za srpskijeziki književnost 17-18, 60-61.

Felbabov, V. 1999. Lažni parovi - englesko/ srpski - u jeziku medija. U R. Šević i dr. (ur.) Zbornik radova VI simpozijum kontrastivna jezička istraživanja. Novi Sad: Filozofski fakultet/Jugoslovensko društvo za primenjenu lingvistiku, 289-294.

Gajić, R. 1984.Lažni paroviu engleskomi srpskohrvatskomjeziku. Neobjavljen magistarski rad. Beograd: Univerzitet u Beogradu, Filozofski fakultet.

Gajić, R. 1985. Elementi analize englesko-srpskohrvatskih lažnih parova. Prevodilac: časopis udruženja naučnih $i$ stručnih prevodilaca Srbije 4/2, 41-46.

Gouws, R. H. et al. 2004. Friends will be friends. - True or False. Lexicographic Approaches to the Treatment of False Friends. [Internet]. Available at: http://tshwanedje.com/ publications/euralex2004-FALSE.pdf [18. 4. 2012].

Granger, S. and H. Swallow. 1988. False friends: a kaleidoscope of translation difficulties. Langage et I'Homme, Vol. 23, fasc. 2, 108-120. [Internet]. Available at: http://sites. uclouvain.be/cecl/archives/Granger_\&_Swallow_1988.pdf [20.4. 2012].

Hlebec, B. 1997. Srpsko-engleski rečnik lažnih parova. Beograd: Trebnik.

Ivir, V. 1968. Serbo-Croat - English False Pair Types. Studia Romanica et Anglica Zagrabiensia 25-26, 149-159.

Ivir, V. 1981. The communicative model of translation in relation to Contrastive Analysis. In W. Kühlwein, G. Thome \& W. Wilss (eds.) Kontrastive Linguistik un Übersetzungswissenschaft. München: Wilhelm Fink Verlag, 209-218.

Ivir, V. 1985. Teorija i tehnika prevođenja - udžbenik za III i IV razreda srednjeg obrazovanja prevodilačke struke. Centar Karlovačka gimnazija, Sremski Karlovci: Zavod za izdavanje udžbenika.

Karavesović, D. 2007. Lažni prijatelji u engleskom i srpskom jeziku u registru vizuelnih medija. Srpski jezik, književnost i umetnost: Zbornik radova s naučnog skupa održanog na Filološko-umetničkom fakultetu u Kragujevcu. Kragujevac: Skupština grada/Univerzitet, Filološko-umetnički fakultet, 359-368.

Koessler, M. and J. Derocquigny. 1928. Les faux amis ou les pièges du vocabulaire anglais. Paris: Vuibert.

Kovačević, Ž. 2011. Lažni prijatelji u engleskom jeziku. Zamke doslovnog prevođenja. 4. izdanje. Beograd: Albatros plus. 
Krzeszowski, T. P. 1990. Contrasting Languages. The Scope of Contrastive Linguistics. Berlin/ New York: Mouton de Gruyter.

Lado, R. 1957. Linguistics Across Cultures. Ann Arbor: The University of Michigan Press.

Prćić, T. 2005. Engleski u srpskom. Novi Sad: ITP „Zmaj".

Prćić, T. 2012. Kako se na engleskom kaže oldtajmer? Anglicizmi kao srpsko-engleski lažni parovi. Zbornik Matice srpske za filologiju i lingvistiku 55/2, 203-220.

Nation, I. S. P. 2001. Learning Vocabulary in Another Language. Cambridge: Cambridge Applied Linguistics.

Simić, M. 2008. Srpsko-engleski lažni parovi: teorijski i praktični aspekti. Filozofski fakultet Univerziteta u Novom Sadu. Neobjavljen diplomski (masterski) rad.

Szpila, G. 2005. False Friends in Dictionaries. Bilingual False Cognates Lexicography in Poland. International Journal of Lexicography 19/1,73-97.

Thornbury, S. 2002. How to Teach Vocabulary. London: Pearson Longman.

Vasić, V., T. Prćić, G. Nejgebauer. 2011.Duyu speak anglosrpski? Rečniknovijih anglicizama. 2. izdanje. Novi Sad: Zmaj.

\section{SUMMARY}

\section{TEACHING TRANSLATION OF ENGLISH-SERBIAN FALSE FRIENDS TO PRIMARY-SCHOOL PUPILS - A NEW APPROACH}

This paper deals with the translation of English-Serbian false friends into Serbian. The research was conducted in a primary school among 22 seventh-grade primaryschool pupils. 14 formal and content-related English-Serbian false friends are used in the research, as well as 6 hidden anglicisms. There are three aims of the paper: first, to help pupils overcome some obstacles they have while translating English-Serbian false friends into Serbian, second, to help them find adequate equivalents for 20 EnglishSerbian false friends and third, to introduce some elements of contact language culture into teaching English as a foreign language. It is expected that if pupils identify similarities and differences among English-Serbian false friends and if they study them through creative activities, they will translate them appropriately. Translation is used as a way of comparing and contrasting English-Serbian false friends. Pupils' mistakes in translation are identified, classified and then, the areas of difficulty in the target language are also found. Consequently, English-Serbian false friends are classified into three groups: adequate, unusual and unacceptable false friends.

KEYWORDS: false friends, teaching, translation, pupils, English, Serbian.

(Original scientific paper received 14.05.2014; revised 20.01.2015; accepted 31.01.2015) 